\title{
The 'developmentalism' debate in Brazil: some economic and political issues
}

\author{
Adriana Moreira Amado* \\ Professor, Department of Economics, Universidade de Brasilia, Brazil \\ Maria de Lourdes Rollemberg Mollo* \\ Professor, Department of Economics, Universidade de Brasilia and Researcher, University of CNPq, \\ Brasilia, Brazil
}

This article analyses different approaches to 'developmentalism,' emphasizing their theoretical origins and identifying their different economic policy implications. Based on the theoretical and empirical characteristics of different growth regimes in Brazil (that is, export-led, demand-led, debt-led, profit-led, and wage-led), the paper recommends that Brazil adopt a 'social developmentalist' growth strategy.

Keywords: developmentalism, Brazilian economy, heterodox thought

JEL code: $B 5$

\section{INTRODUCTION}

The main aim of this article is to contribute to the debate on the 'developmentalism' agenda. After a long period of neoliberal intellectual dominance in both Brazil and the World, development is again being discussed as a deliberate strategy of State and not just a side-effect of market mechanisms. Bresser-Pereira (1991; 2004; 2006; 2007; 2011) has been a significant contributor to this turning point with his propositions regarding 'new developmentalism.'

Mainstream theory identifies development, or growth, as a supply-side market-driven phenomenon that delivers improved resource allocation and productivity. The 'developmentalism' perspective is associated with heterodox thinking in that it sees a central role for the State in the growth process and social transformation. It also views the demand side of the economy as providing the main forces pushing for development. However, there is disagreement within this perspective as to what sort of demand is responsible for pushing development. That disagreement is a central focus of this paper.

The paper begins in Section 2 with a taxonomy of the different branches of 'developmentalism.' In Section 3, it surveys the literature on export-led, demand led, debt-led, profit-led, and wage-led development. The paper concludes in Section 4 with some observations on what is most suitable for Brazil.

* The authors (uctpaa@unb.br and mlmollo@unb.br) are professors in the Department of Economics at the University and researchers at CNPq. The authors thank Thomas Palley for his extensive comments and editorial assistance. 


\section{DEVELOPMENTALISM AND ITS APPROACHES}

The classification proposed in this article identifies four main branches of 'developmentalism.' The first branch is labeled 'pioneer developmentalism' and is associated with the work of the Economic Commission for Latin America (ECLA). It has a closer proximity to mainstream theory, especially regarding the role given to saving in the growth process. The second branch is labeled 'new developmentalism' and it is closely associated with the work of Bresser-Pereira (1991; 2004; 2006; 2007; 2011). It draws significantly on the work of ECLA, and like ECLA's approach it too has close links to orthodoxy. The third approach is labeled 'post-Keynesian developmentalism,' and it is closely associated with economists at the Federal University of Rio de Janeiro. The fourth approach is labeled 'social-developmentalism.' It embeds a form of structuralist fundamentalism, but with a more leftist perspective. It also incorporates post-Keynesian ideas regarding the role of the State. The Marxist dimension concerns the necessity of a better insertion of the labor force and transformation of the relation between Capital and Labor.

\subsection{Pioneer developmentalism}

Pioneer developmentalism has its roots in the work of the Economic Commission for Latin America (ECLA), as do the majority of the approaches analysed here. However, within the ECLA approach there are disagreements and these are reflected in the different 'developmentalism' perspectives.

ECLA's theoretical perspective is deeply rooted in the discussion of economic development and concerns about the long run (Furtado 1959). Those original ideas were substantially heterodox and combined several aspects of heterodox thought. The focus was development in the periphery and it was characterized by eclectic freedom of thought. Consequently, the initial formulation contained many ideas that were close to the mainstream perspective.

In terms of the real versus monetary debate, the original ECLA approach opted for real analysis. When the monetary sphere was addressed, the theoretical frame was almost always orthodox in perspective. There are some possible explanations for this. The most obvious seems to be that at the time when ECLA's contributions were developed, the main focus of Keynesian economics was the real sector. Notwithstanding that, the obvious contributions of Keynes to monetary analysis, the development of a Keynesian monetary approach, only happened in the 1970 s with the emergence of the postKeynesian development school and its notion of a 'Monetary Production Approach' (Keynes 1980; 1983a; 1983b; Carvalho 1992). Furthermore, some of Keynes's more heterodox analysis was only published in the Collected Writings, released in the 1970s. As Carvalho (1992, p. 171) points out, this material was fundamental to the building of the post-Keynesian school of thought. Instead of emphasizing monetary aspects in its analysis, ECLA was heterodox in methodological terms. Thus, the ECLA approach adopted the historical-structural method, which emphasizes that real and historical processes are critically important for understanding the economy and its transformation via development. This was one of ECLA's major theoretical contributions (Furtado, R., in Furtado 1960 [2009]).

Underdevelopment was understood as associated with structural characteristics that are the side-effect of capitalist development itself. It is characterized by structural heterogeneity and a specific form of insertion in the international trading system. This insertion promotes the transfer of the gains from technical change in the periphery to the center, 
which reduces the endogenous dynamization of technical progress within the periphery. The reasons for this transference are the character of market structures in the periphery and center and the income and price elasticities of trade (Rodriguez 1981).

These elements create an extremely concentrated income distribution in the periphery, which accentuates the restrictions imposed by the balance of payments constraint in those countries and does not allow the development of a dynamic internal market because the structure of demand is incompatible with the technical possibilities of supply.

For ECLA, the focus of the problem is technical dependence. This dependence deepens the problem of productivity and distorts the use of resources in the periphery, which in turn amplifies the balance of payments constraint (Furtado 1960 [2009], p. 173).

These elements generate a self-fulfilling outcome: deepening of structural excess of labor supply, balance of payments restrictions, and increase in costs of production. At the same time, the structural heterogeneity in the labor market is amplified by the whole process.

Escaping underdevelopment entails overcoming those structural limits via technical development, economic diversification based on the internal market, and creation of an internal economic dynamic. However, this process is not possible via market mechanisms alone. State action, which plans and coordinates the actions of the private sector, is also essential (Bielschowsky 2010).

\subsection{State and development: orthodox and heterodox perspectives on monetary theory}

The ECLA Structuralist perspective has germinated several heterodox views about 'developmentalism,' each of which emphasizes a different aspect of the process. Before turning to an examination of those views, it is worth noting some major distinguishing features between orthodox and heterodox perspectives.

Orthodox economics views the loanable funds market as essential for comprehension of the growth process as it determines the level of saving and investment. The supply of loanable funds is determined by savings, which are the non-expended income. The demand for loanable funds is determined by investment. On the supply side, the interest rate represents the reward for delayed consumption. On the demand side, it represents the marginal contribution of investment to expanding production capacity. The loanable funds market guides the growth process without inflationary pressure. Savings fund investment and investment assures an increased flow of consumption goods in future periods. In this schema, using monetary expansion to stimulate growth by increased investment or consumption tends to put upward pressure on prices. Using fiscal policy to stimulate growth results in crowding-out of private investment.

As regards the growth effectiveness of monetary policy, mainstream economics emphasizes the idea of neutrality of money. In the weak version, money is neutral in the long run: in the strong version, it is neutral in both the short run and the long run.

Heterodox economics holds a completely different position. In a monetary production economy, which is the central concept for this school, money is intrinsically non-neutral in both the short and long run. Thus, both economic policy and state action are fundamental in the growth process.

\subsection{New developmentalism}

New developmentalism is significantly associated with the work of Bresser-Pereira (2006; 2007; 2011) and it emphasizes external markets as the main driver of economic 
development in peripheral countries. It also emphasizes the importance of fiscal balance for economic growth. The inspiration for the approach comes from the export-led growth model followed by some Asian countries.

There are also some similarities with Prebisch's approach. Prebisch $(1961$, p. 7) observed that inflationary forces in peripheral countries tend to appear as a consequence of structural problems and lack of savings to finance investment. This position is shared by Furtado (1960 [2009]), who is considered by Bielschowsky to be an odd Keynesian because of his concern with savings (Bielschowsky 1988, p. 160). Prebisch and Furtado point out that the state should act to redirect demand from imports to domestic production, and should also redirect expenditure in order to allow investment to take place with adequate non-inflationary funding from domestic savings (Furtado 1960 [2009], pp. 31, 47). In this sense, prior savings are considered fundamental for investment, and insufficient saving is responsible for inflation. This Keynesian 'saving gap' approach has considerable similarity with the orthodox perspective.

The new developmentalist position was initially presented by Bresser-Pereira $(1991 ; 2004 ; 2006 ; 2007 ; 2011)$ and was then further developed in co-authored work with Nakano (Bresser-Pereira and Nakano 2002) and Gala (Bresser-Pereira and Gala 2007), and most recently with Oreiro (Bresser-Pereira 2011 and Oreiro 2012). The broad recommendation is that the economy be oriented towards external demand (exports). The exchange rate should be devalued in order to make the industrial sector internationally competitive, and this should be done via a low interest rate policy. The key variable for economic policy should be the exchange rate. This economic development model should be outward oriented and should look to take advantage of local specificities like cheap labor in order to increase exports. Upon reflection, this perspective can been seen to have close connections to the balance-of-paymentsconstrained growth approach developed by Thirlwall (Thirlwall 1980; Thirlwall and Hussain 1982).

The potential for inflation caused by exchange rate devaluation explains why the pioneers of new developmentalism insist on fiscal balance and fiscal responsibility. This insistence links them to traditional mainstream economics.

The original ECLA structuralist perspective emphasized a much wider set of concerns and constraints than just the export sector. Stimulus to the export sector can be ineffective if other structural changes are not also promoted. Underdevelopment is not just about limits on exports, as pointed out by Rodriguez (1981). Indeed, those limits are themselves consequences of structural problems which characterize underdevelopment such as structural heterogeneity and technical dependence. New developmentalism does not address any of these constraints. Instead, its focus is exclusively on the export sector. Furthermore, narrow export-oriented policy can potentially worsen these structural problems. For instance, if a country is mainly an exporter of primary products, focusing on exports can worsen the structural constraint associated with low income and price elasticities. Changing the composition of the external sector is the key problem, and this requires intense state action.

As regards income distribution, Prebisch (1961) presents explicit prescriptions regarding the necessity of promoting a better income distribution in Latin America. However, income distribution does not seem to be a major concern of new developmentalists, as is evident in Oreiro (2012), who explicitly defends the idea of reducing wage pressure in order to avoid profit share compression constraining the growth process. For all of these reasons, the new developmentalism perspective seems to have a more mainstream and conservative inclination. 


\subsection{Post-Keynesian developmentalism}

Post-Keynesian developmentalism adopts a fundamentally different approach that focuses on external vulnerability associated with liberalization of the financial account. The theoretical inspiration of this group derives from Keynes and his General Theory (1936), especially regarding concerns about the relevance of uncertainty for understanding the economic process.

The post-Keynesian perspective is critical of orthodox economics and its denial of fundamental uncertainty. In a world without uncertainty it is not possible to theorize about liquidity preference, as the concept makes no sense. The same holds for the concept of the marginal productivity of capital. Instead, in a world of uncertainty the appropriate concept is the marginal efficiency of capital, which reflects the uncertain character of a monetary production economy and relies on knowledge conventions to guide the investment decision-making process (Keynes $1983 \mathrm{a}$ and b).

According to Keynes (1983a; 1983b), the loanable funds approach is false and there is no need for prior savings to fund investment. Instead, investment requires an adequate credit supply at reasonable interest rates relative to the marginal efficiency of capital. Saving is a side-effect of investment and so is a consequence and not a condition of investment. Saving is generated by an increase in income brought about through the multiplier process. However, the accompanying financial liability structure is fundamental. Thus, the financing mechanism must be via long-term liabilities that avoid excessive financial risk exposure of economic entities and the economy. This requires liquid and deep capital and financial markets. Consequently, the existence of institutional mechanisms that assure the existence of an adequate supply of long-term finance is fundamental for the stability of investment and the growth process.

The state has a vital role to play in this process. Its role is to ensure a stable process of growth, thereby giving confidence to agents so that they are willing to reduce their liquidity preference. The instruments for accomplishing this are fiscal and monetary policy.

In terms of monetary policy, the state should promote low interest rates in order to stimulate investment. The lower the interest, the higher the number of projects with a marginal efficiency of capital in excess of the interest rate threshold and the greater the level of aggregate investment. Policy can also help develop financial markets so as to create a variety of assets with features attractive to wealth holders and business borrowers, thereby facilitating the provision of long-term financing for capital accumulation.

However, actual investment outcomes are always hostage to the subjectivity of agents regarding their perceptions of uncertainty and liquidity preference. If agents are more uncertain and have a greater liquidity preference, investment will be reduced. This is the main reason for Keynes's preference for fiscal policy, as it depends only on the action of Government. Increased government expenditure increases income, which increases demand and the marginal efficiency of capital while reducing liquidity preference. That stimulates investment, thereby increasing growth.

For post-Keynesian developmentalists, the key instrument is the interest rate. This contrasts with new developmentalists, who view the exchange rate as the key instrument.

What about income distribution? Carneiro (2012) claims post-Keynesian developmentalists have little concern with this matter, but that is contested by Sicsú et al. (2005, p. XLIII). According to Sicsu et al., post-Keynesian developmentalism proposes measures to assure that investment takes place, and, among those measures, increasing aggregate demand is one of the most important. A second measure is regulation of the market to avoid concentration and monopoly. A third concern is external 
vulnerability which demands direct state action in the financial sphere to protect against financial capital flow disruptions. A fourth concern is with innovation, the need to assure technology transfer, and developing a national innovation system. Finally, there is a concern with social and economic equity, which is to be met by a high and continuous rate of growth that creates a bigger economic pie to satisfy growing aspirations.

As pointed out by Morais and Saad-Filho (2011), within these ideas there is no explicit mention of internal demand. The focus remains the external market, but it is framed in terms of 'modern protectionism' (Sicsú et al. 2005, p. XLVI) associated with protecting the capital account. The main aim of this is to avoid the external vulnerability and reduce attractiveness and vulnerability to foreign speculative capital, thereby allowing a more competitive exchange rate.

This approach tends to give less importance to the real side of the economy. However, there are some post-Keynesian developmentalist authors that emphasize the idea of a 'monetary production economy' and in doing so they recognize the interaction between monetary and real variables. This perspective is normally associated with the integration of the real side in a center-periphery model. It shows the importance of the state as the only agent capable of breaking the vicious circles that characterize center-periphery relations (Dow 1982; 1987; 1990; Amado 1997; Rodriguez-Fuentes 2005; Resende and Amado 2007).

\subsection{Social developmentalism}

Policies focused on income distribution play a central role for the third group, labeled 'social developmentalists.' This group sees the internal market as one of the main forces pushing development. It specifically focuses on increased wages and improved income distribution, hence the notion of 'social developmentalism' suggested by Bastos (2012). This group is also strongly linked to the tradition of Marxian analysis.

Ironically, Marxian analysis can also share features in common with orthodoxy when it comes to criticism of state policies that try to promote development by increasing wages. The argument is that investment needs prior savings. Since savings are generated by profits, increased wages reduce profits and, consequently, reduce savings. The increase in wages therefore reduces investment and income. Lavoie and Stockhammer (2012), for instance, point out that some Marxists do not believe that pro-labor policies work in a profit-led regime, and such policies have only temporary positive effects. However, there is no consensus among Marxist analysts regarding the role of the State and pro-labor development policies.

The Marxist debate regarding the role of the State is long-standing. Poulantzas (1971) and Miliband (1973) are major contributors. According to Poulantzas (1971, p. 40), the State has a special role in creating 'cohesion' at the economic, political, and ideological levels, and its function is to equilibrate and regulate social formation. In this way, there is a degree of autonomy of the State in relation to classes. In contrast, Miliband (1973, p. 87) argues there is no autonomy as the State is just the representative of the interests of the bourgeoisie. Jessop (1991) presents a more contemporary view rooted in this tradition, and argues that the state maintains some degree of autonomy. Holloway (1991, p. 251) denies that autonomy.

The perspective of the state that is adopted by social developmentalists sees the state as a relatively autonomous institution. That allows for formulation of economic policies, which can promote gains for the working class and improve income distribution (Mollo 2001 [2012]). This contrasts with the view of the state as captive of the 
bourgeoisie, which means the State can only work on behalf of capital's interests and, therefore, cannot play a role in promoting a better position for workers in the class struggle. ${ }^{1}$

Social developmentalists argue that increased employment increases the market power of workers, thereby potentially increasing wages and improving workers' position within the capital-labor relation. However, this is not the only effect that can be observed. After the debates among Marxists in the 1970s, there is a post-scriptum based on observations from the neoliberal decade of the 1980s. Lewrg (1980) concludes that neoliberalism worsens the situation of workers, weakening their position in the capital-labor relation and contributing to a substantial loss of working class organization power.

As regards the role of money, Marxists believe in non-neutrality because credit can amplify production and the productive potential of the economy by improving the coordination of capital in the phases of capital reproduction, thereby avoiding increased prices (Mollo 2004). Consequently, the state can use monetary and financial policy to stimulate growth and employment. On the other hand, credit can also accentuate crises. This provides a negative channel of effect, but it also further confirms the non-neutrality of money.

The key instrumental variable for social developmentalism is mass consumption, which is to be stimulated. According to Bielschowsky (2012), the potential of the Brazilian internal market represents an 'extraordinary opportunity.' Mass production and consumption allow increased returns to scale regarding productivity and technical change. That can support higher wages and strengthens backward and forward linkages, including those with deeper technological density, which integrates a good growth and income distribution dynamic. For Bielschowsky, mass consumption is one of the three fundamental engines of economic development in Brazil, the others being natural resources and infrastructure.

The social developmentalist perspective raises concerns about the new developmentalist prescription of competitiveness through devaluation of the exchange rate because it has negative effects on real wages. Additionally, industrial policy based only on the exchange rate does not generate the structural changes that are necessary for development (Mollo and Fonseca 2013).

\section{GROWTH REGIMES AND DEVELOPMENT STRATEGIES: TAKING PART}

Growth regimes refer to policy configurations that emphasize leadership of different variables for the promotion of growth. The heterodox perspective emphasizes demand stimulus as the over-arching driver of growth. This section examines alternative heterodox growth regimes in which different policy variables are enlisted to stimulate demand.

Demand can be either foreign or domestically generated, and it can be either private or public (government) demand. Hein and Mundt (2012) present a taxonomy that divides countries into four groups according to the source of demand: (a) debt-led demand that stimulates consumption; (b) strongly export-led demand; (c) internally led demand; and (d) moderately export-led demand. According to these authors, this characterization is useful for understanding the recent economic evolution of several countries, the influence of financialization on their patterns of development, and the

1. Fiori (2011; 2012a; 2012b) has criticized the Marxian position, showing that their prescriptions do not have any transformative power. 
decrease in the wage share of GDP after the crises that began in 2008. The taxonomy helps point to some possible solutions.

In an economy led by credit-financed consumption, there is a huge deficit in the balance of payments, and private and public borrowing serve to compensate for the decrease in consumption that would otherwise follow from the decrease in labor's share of income. By contrast, economies that are largely dependent on exports compensate for this reduction in consumption via increased exports. Such economies are mercantilist since they have a large surplus in the balance of payments which compensates for the reduction in their internal demand. Economies driven by internal demand also have deficits in their balance of trade, but can have either private sector surpluses or government sector deficits. Finally, the economies moderately driven by exports, such as Brazil, have a small balance of payments surplus which partially compensates for weak internal demand. Hein and Mundt (2012) analyse several countries between 1980 and the beginning of the 2000. The period after 2000, when there was a rapid reduction of inequality in Brazil, is not analysed.

This characterization allows introduction of another important analytic dimension regarding the distinction between wage-led and profit-led economies. This distinction concerns the process of accumulation and the response to changes in the functional distribution of income.

... a wage-led demand regime means that an increase in the wage share leads to an increase in aggregate demand. The wage-led scenario may arise when higher wages lead to higher consumption expenditures (higher consumption sales may then also induce higher investment expenditures). Conversely, a profit-led demand regime means that an increase in the wage share leads to a decline in aggregate demand. (Stockhammer 2011, p. 5).

An increased wage share increases consumption, thereby increasing production and employment. That generates an accelerator effect that increases investment and growth (Rowthorn 1981; Dutt 1987). On the other hand, an increased wage share represents an increase in costs and reduction in profitability, which has a negative impact on investment and growth (Bhaduri and Marglin 1990; Kurz 1990). This generates a conflict that is summarized by Lavoie and Stockhammer (2012, p. 11) as follows:

If the profitability effect is weak (relative to the consumption effect and the accelerator effect), with the investment function not dropping below ..., then both GDP and investment are higher following the increase in real wages. In this case, both the short-run and the longrun effects are favourable to the economy. We will then say that the economy is experiencing a wage-led demand regime as well as a wage-led investment regime, since GDP is rising in the short-run but is also likely to grow faster in the long-run, thanks to the higher rate of investment. In the intermediate case, the profitability effect will lead to a shift of the investment curve somewhere between ... In this case, higher real GDP generates a higher output level but investment will be lower. We will then say that the economy is still in a wage-led demand regime, while belonging to a profit-led investment regime. This is because GDP is rising in the short-run, but likely to grow more slowly in the long-run, due to the lower investment level. Finally, we have the third case, which occurs when the profitability effect shifts the investment function below the $\mathrm{I} 2$ curve, meaning that the increase in real wages provokes a reduction in real output and a reduction in investment expenditures. This case corresponds to both a profit-led demand regime and a profit-led investment regime.

Marxists (dos Santos 2013a; 2013b) criticize this perspective as being based on a false model of capital reproduction. Foley $(1982 ; 1986)$ demonstrates different relations between production and distribution than those observed by the wage-led model. 
According to the Marxist perspective, in the complete capital reproduction cycle, represented by $\mathrm{M} \rightarrow \mathrm{C} \rightarrow \mathrm{P} \rightarrow \mathrm{C}^{\prime} \rightarrow \mathrm{M}^{\prime}$, where $\mathrm{M}=$ money, $\mathrm{C}=$ commodities, and $\mathrm{P}=$ production, $\mathrm{M} \rightarrow \mathrm{M}^{\prime}$ is a dynamic process. It begins with monetary expenditures made by capitalists with wages and means of production, which is then transformed via production $(\mathrm{P})$ into goods with a higher value than the initial expenditures (M). Profits are only generated in the fourth step, when the goods are sold $\left(\mathbf{M}^{\prime}\right)$. Within this process, income distribution is determined via the different steps. Wages depend on the initial expenditures, while profits are only realized after the sale of goods at the end of the process. Contrary to the wage-led perspective, wages and profit are determined as a consequence of the reproduction of capital process, and not as a consequence of a previous distribution or as a consequence of the simultaneous distribution with product shared between wages and profits.

Taking into consideration the entire capital reproduction cycle demonstrates that, contrary to what wage-led proponents postulate, increases in the wage share of income do not come from mass consumption, but instead come from investment because it generates employment and wages. Mass consumption only affects profits in the step when goods are sold. Thus, the conclusion of these models is that instead of discussing wage-led or profit-led growth, it is better to discuss growth led by investment or mass consumption.

Recent literature provides several reasons that strengthen the social developmentalist hypothesis. These arguments are:

1. In Brazil there are few studies that clearly demonstrate whether the relevant model is wage-led or profit-led. A recent article by Bruno (2012) concludes that in Brazil the relevant model is wage-led. However, new developmentalists suggest that the fall in wages is positive because it increases growth by making exports competitive. They therefore actually argue in favor of a profit-led model for Brazil, pointing out that the wage-led model is not competitive in the long run (Oreiro 2012). Balanced against that, Onaran and Stockhammer (2002) demonstrate that the fall of wages was unable to improve investment in industry in the case of Turkey.

2. Palley $(2011 ; 2012)$ points out that the export-led model is part of mainstream prescriptions and incorporates many orthodox elements such as: (a) the theorem Hecksher-Ohlin-Samuelson, which demonstrates the mutually beneficial nature of trade; (b) the idea that opening the economy reduces rent-seeking behavior and disciplines governments; and (c) trade and an open economy structure encourage knowledge spillover effects that increase growth. However, none of these features applies to the reality of the contemporary Brazilian economy with its increasing inequality, crisis, and difficulty of realizing growth. Therefore, they are not a good guide to overcoming underdevelopment in a country with the structural problems of Brazil.

3. There are several studies that show a predominance of the wage-led structure in many countries. Onaran and Galanis (2012) analyse 16 G20 countries and conclude that the negative consumption effect of increased profit shares dominates the positive investment effect, indicating that they all have an internal demand structure that is wage-led. Countries are only profit-led when the positive distribution effect on net exports is sufficiently strong as to compensate the negative effect on internal demand. They also argue that the world economy as a whole is wage-led. In a globalized economy, a reduction in wage shares hurts all economies, including those that are profit-led. The conclusion is that policies of 'beggar the neighbor' are not productive at any level. 
4. Palley $(2011 ; 2012)$ points out other problems associated with the export-led strategy. First, the stagnation that has followed the crisis is the result of demand shortage and US demand is unlikely to recover its previous robustness because of debt saturation. Second, increased demand from emerging economies is not likely to be sufficient to overcome the global demand shortage. Third, the export-led growth model promotes race-to-the-bottom competition between emerging countries to gain competitiveness by reduced wages and regulation, especially regarding environmental issues and social standards. These features demonstrate the limits of export-led strategies.

The above observations point to core problems with new developmentalism which recommends the adoption of an export-led growth strategy. We now turn to some arguments that explain why a social developmentalist regime offers better growth and development prospects for the Brazilian economy:

1. Social developmentalism is superior to other strategies in terms of social justice.

2. Social developmentalism relies on internal demand as the main engine of the economy. Internal demand has been shown historically to be effective and it is also responsible for the recent improvement of growth of the Brazilian economy.

3. Brazil's industrial development is the main concern of perspectives on both the left and right. Social developmentalism focuses on this sector, and is concerned with the improvement of linkages with high density technological sectors as well as traditional sectors. These linkages are fundamental to the growth process, especially the backward linkages that support internal demand. This strategy therefore tackles two problems: deindustrialization and structural changes that diminish scale gains and technical change, with potentially adverse effects on income distribution. In this way it reduces structural heterogeneity, which is seen as one of the main causes and consequences of underdevelopment.

4. The priority given to investment to increase employment and wages is important for both Marxists and Keynesians. Investment is a priority in an internal market strategy, and it can in turn promote mass consumption by raising wages. Marxist analysis emphasizes the role of profits in spurring investment and wage gains to follow from economic growth caused by investment. Keynesian models attribute a direct causal role to wages, with higher wages raising demand and capacity utilization, and thereby spurring investment. This wage-capacity utilization channel of effect on investment distinguishes Keynesian models from Marxist models.

5. Once wage increases are assured by internal demand created by investment, there are no exogenous constraints preventing improvements in income distribution via policies such as an increased minimum wage or income transfers.

6. Investment should focus on the industrial sector and this is more likely to happen if the growth strategy focuses on internal demand because entrepreneurs tend to be more responsive to this source of demand than to external demand (Bielschowsky 2012).

\section{CONCLUDING REMARKS}

This paper has explored the diversity of branches of contemporary 'developmentalism' in Brazil, tracing their theoretical affiliations and differences regarding economic policy prescriptions. Special emphasis was given to the key variables for development in each group: structural transformation for pioneer developmentalism; exchange rate 
management for new developmentalism; interest rate management for post-Keynesian developmentalism; and income distribution for social developmentalism. New developmentalism, post-Keynesian developmentalism, and social developmentalism all emphasize increased demand as a driver of economic development, and this is the unifying feature in heterodox analysis.

The paper supports the social developmentalist perspective, particularly because it does best at improving the economic position of the working class which constitutes the great majority of the population. The social developmentalist approach emphasizes increased investment and consumption spending, and it is fully consistent with the lower interest rate and financial market stability strategy proposed by post-Keynesian developmentalists.

The new developmentalist policy focus on exchange rate devaluation is viewed with concern. On the one hand it provides a benefit by reducing the leakage of demand and employment caused by imports, but on the other it imposes negative effects on real wages via inflation and race-to-the-bottom competitive pressures. However, social developmentalism also recognizes that the exchange rate is a key variable and should be managed by the State, albeit for different ends.

\section{REFERENCES}

Amado, A.M. (1997), Disparate Regional Development in Brazil: A Monetary Production Approach, Aldershot, UK: Ashgate.

Bastos, P.P.Z. (2012), 'A Economia Política do Novo-Desenvolvimentismo e do Social Desenvolvimentismo,' Economia e Sociedade, 21(346), 779-410.

Bhaduri, M. and Marglin, S. (1990), 'Unemployment and the Real Wage: The Economic Basis for Contesting Political Ideologies,' Cambridge Journal of Economics, 14, 375-393.

Bielschowsky, R. (1988), Pensamento Econômico Brasileiro: o Ciclo Ideológico do Desenvolvimentismo, Rio de Janeiro: IPA/INPES.

Bielschowsky, R. (2010), 'Vigência das Contribuições de Celso Furtado ao Estruturalismo,' Revista de la CEPAL, 109, 183-191.

Bielschowsky, R. (2012), 'Estratégia de Desenvolvimento e as Três Frentes de Expansão no Brasil: Um Desenho Conceitual,' Economia e Sociedade, 21, Número Especial, 729-747.

Bresser-Pereira, L.C. (ed.) (1991), Populismo Econômico: Ortodoxia, Desenvolvimentismo e Populismo na América Latina, São Paulo: Nobel.

Bresser-Pereira, L.C. (2004), 'Novo-Desenvolvimentismo,' Folha de S. Paulo, 9 September.

Bresser-Pereira, L.C. (2006), 'O Novo Desenvolvimentismo e a Ortodoxia Convencional,' São Paulo em Perspectiva, 20(3), 5-24.

Bresser-Pereira, L.C. (2007), 'Estado y Mercado en el NuevoDesarrollismo,' Nueva Sociedad, 210, 110-125.

Bresser-Pereira, L.C. (2011), 'An Account of New Developmentalism and the Structuralist Macroeconomics,' Revista de Economia Política, 31(3), 493-502.

Bresser-Pereira, L.C. and Gala, P. (2007), 'Por Que a Poupança Externa Não Promove Crescimento,' Revista de Economia Política, 27(1), 3-19.

Bresser-Pereira, L.C. and Gala, P. (2010), 'Macroeconomia Estruturalista do Desenvolvimento,' Revista de Economia Política, 30(4), 663-686.

Bresser-Pereira, L.C. and Nakano, Y. (2002), 'Uma Estratégia de Desenvolvimento com Estabilidade,' Revista de Economia Política, 21(3), 3-27.

Bresser-Pereira, L.C. and Nakano, Y. (2003), 'Crescimento Econômico com Poupança Externa?' Revista de Economia Política, 22(2), 3-27.

Bruno, M. (2012), 'Growth Regime and Capital Accumulation in Brazil: A Preliminary Analysis of the Liberalization Period,' mimeo.

Carneiro, R. (2012), 'Velhos e Novos Desenvolvimentismos,' Economia e Sociedade, 21, Número Especial, 749-778. 
Carvalho, F.C. (1992), 'Moeda, Produção e Acumulação: Uma Perspectiva Pós-Keynesiana,' in Silva, M.L.F. (ed.), Moeda e Produção: Teorias Comparadas, Brasília: Editora UnB, pp. 163-194.

dos Santos, P.L. (2013a), 'Production and Consumption Credit in a Continuous-Time Model of the Circuit of Capital,' Historical Materialism, 17(2), 180-213.

dos Santos, P.L. (2013b), 'Demand, Production and the Determinants of Distribution: A Caveat on "Wage-Led Growth",' Working Paper Series number 323, PERI - Political Economy Research Institute, May.

Dow, S.C. (1982), 'The Regional Composition of the Money Multiplier Process,' Scottish Journal of Political Economy, 29(1), 22-44.

Dow, S.C. (1987), 'The Treatment of Money in Regional Economics,' Journal of Regional Science, 27(1), 13-24.

Dow, S.C. (1990), Financial Markets and Regional Economic Development: The Canadian Experience, Aldershot, UK: Ashgate.

Dutt, A.K. (1987), 'Alternative Closures Again: A Comment on "Growth, Distribution and Inflation",' Cambridge Journal of Economics, 11(1), 75-82.

Fiori, J.L. (2011), 'A Miséria do "Novo Desenvolvimentismo", Carta Maior, 30 November.

Fiori, J.L. (2012a), 'O "Desenvolvimentismo de Esquerda",' Carta Maior, 13 November.

Fiori, J.L. (2012b), 'Desenvolvimentismo e "Dependência”,' Carta Maior, 13 November.

Foley, D. (1982), 'Realization and Accumulation in a Marxian Model of the Circuit of Capital,' Journal of Economic Theory, 28(2), 300-319.

Foley, D. (1986), Money, Accumulation and Crisis, Fundamentals of Pure and Applied Economics series, vol. 2, London: Harwood Academic Publishers.

Furtado, C. (1959), Formação Econômica do Brasil, Rio de Janeiro: Ed. Fundo de Cultura.

Furtado, C. (1960 [2009]), Desenvolvimento e Subdesenvolvimento, Rio de Janeiro: Contraponto.

Hein, E. and Mundt, M. (2012), 'Financialisation and the Requirements and Potential for WageLed Recovery - A Review Focusing on the G20,' Conditions of Work and Employment Series, n. 37, Geneva: International Labour Office.

Holloway, J. (1991), 'The State: An Every Day Struggle,' in Clarke, S. (ed.), The State Debate, London: Macmillan, pp. 225-268.

Jessop, B. (1991), 'Regulation Theory, Post Fordism and the State: More Than a Reply to Werner Bonefeld,' in Bonefeld, W. and Bolloway, J. (eds), Post-Fordism and Social Form: A Marxist Debate on the Post-Fordist State, London: Macmillan, pp. 145-169.

Keynes, J.M. (1936), A Teoria Geral do Emprego em Economia e Ciências Sociais, Lucas, Fábio (ed.), Rio de Janeiro: Zahar.

Keynes, J.M. (1980), 'Activities 1940-1946 Shaping the Post-War World: Employment and Commodities,' The Collected Writings of John Maynard Keynes, vol. 27, London: Macmillan.

Keynes, J.M. (1983a), 'Alternative Theories of the Rate of Interest,' The Collected Writings of John Maynard Keynes, vol. 14, London: Macmillan and Cambridge University Press.

Keynes, J.M. (1983b), 'Mr. Keynes' Finance,' The Collected Writings of John Maynard Keynes, vol. 14, London: Macmillan and Cambridge University Press.

Kurz, H. (1990), 'Technical Change, Growth and Distribution: A Steady-State Approach to Unsteady Growth,' in Kurz, H. (ed.), Capital, Distribution and Effective Demand: Studies in the Classical Approach to Economic Theory, Cambridge, UK: Polity Press, pp. 210-239.

Lavoie, M. and Stockhammer, E. (2012), 'Wage-led Growth: Concept, Theories and Policies,' Conditions of Work and Employment Series, 41, Geneva: International Labour Office.

Lewrg (The London-Edinburgh Weekend Return Group) (1980), In and Against the State, London: Pluto Press.

Miliband, R. (1973), 'Poulantzas and the Capitalist State,' New Left Review, 82, 83-92.

Mollo, M.L.R. (2004), 'Ortodoxia e Heterodoxia Monetárias: A Questão da Neutralidade da Moeda,' Revista de Economia Política, 24(3), 323-343.

Mollo, M.L.R.A. (2001 [2012]), 'A Concepção Marxista de Estado: Considerações Sobre Antigos Debates com Novas Perspectivas,' Economia, ANPEC, 2(1), janeiro/junho 2001, 348-388; 
and in Chitolina, C.L., Pereira, J.A., Oliveira, L.B., and e Bordin, R.A, (eds), 2012, Estado, Indivíduo e Sociedade: Problemas Contemporâneos, Jundiaí-SP: Paco Editorial, pp. 249-280.

Mollo, M.L.R. and Fonseca, P.D. (2013), 'Desenvolvimentismo e Novo-Desenvolvimentismo: Raízes Teóricas e Precisões Conceituais,' Revista de Economia Política, 33(2), 121-141.

Morais, L. and Saad-Filho, A. (2011), 'Da Economia Política à Política Econômica: o NovoDesenvolvimentismo e o Governo Lula,' Revista de Economia Política, 31(4), 527-547.

Onaran, O. and Galanis, G. (2012), 'Is Aggregate Demand Wage-Led or Profit-Led? National and Global Effects,' Conditions of Work and Employment Series, n. 31, Geneva: International Labour Office.

Onaran, O. and Stockhammer, E. (2002), 'Two Different Export-oriented Growth Strategies under a Wage-led Accumulation Regime: à la Turca and à la South Korea,' Political Economy Research Institute, University of Massachusetts Amherst Working Paper Series n. 38.

Oreiro, J.L.C. (2012), 'Novo-Desenvolvimentismo, Crescimento Econômico e Regimes de Política Monetária,' Estudos Avançados, 26(75), 29-40.

Palley, T. (2011), 'The Contradictions of Export-Led Growth,' Levy Institute of Bard College, Public Policy Brief, n. 119.

Palley, T. (2012), 'The Rise and Fall of Export-Led Growth,' Investigacion Economica, LXX, 280, 15-35.

Poulantzas, N. (1971), Pouvoir Politique et Classes Sociales, Paris: Maspero.

Prebisch, R. (1961), O Falso Dilema entre Desenvolvimento Econômico e Estabilidade Monetária, São Paulo: Ordem dos Economistas de SP.

Resende, M.F.C. and Amado, A.M. (2007), 'Liquidez Internacional e Ciclo Reflexo: Algumas Observações para a América Latina,' Revista de Economia Política, 27(1), 41-59.

Rodriguez, O. (1981), Teoria do Subdesenvolvimento da CEPAL, Rio de Janeiro: Forense Universitária.

Rodriguez-Fuentes, C. (2005), Regional Monetary Policy, New York: Routledge.

Rowthorn, R. (1981), 'Demand, Real Wages and Economic Growth,' Thames Papers in Political Economy, Autumn, 1-39.

Sicsú, J., Paula, L.F., and Michel, R. (2005), 'Introdução,' in Sicsú, J., Paula, L.F., and Michel, R. (eds), Novo-Desenvolvimentismo: um Projeto Nacional de Crescimento com Equidade Social, Barueri-SP: Manole e Rio de Janeiro: Fundação Konrad Adenauer.

Stockhammer, E. (2011), 'Wage-Led Growth: An Introduction,' Economics Discussion Papers, 2011-1, London, Kingston University.

Thirlwall, A.P. (1980), 'Regional Problems are Balance of Payments Problems,' Regional Studies, 14, 419-425.

Thirlwall, A.P. and Hussain, M.N. (1982), 'The Balance of Payments Constraint, Capital Flows and Growth Rate Differences between Developing Countries,' Oxford Economic Papers, 34(3), $458-510$. 